\title{
PENGARUH MODEL PEMBELAJARAN KOOPERATIF TIPE TEAMS GAMES TOURNAMENT (TGT) TERHADAP MOTIVASI BELAJAR IPA DI KELAS IV SDN KELAPA DUA 06 PAGI JAKARTA BARAT
}

\author{
Syifa Aulia Hakim ${ }^{1},{ }^{*}$, Harlinda Syofyan ${ }^{2}$ \\ ${ }^{1}$ Fakultas Keguruan dan Ilmu Pendidikan, Universitas Esa Unggul \\ ${ }^{1}$ Fakultas Keguruan dan Ilmu Pendidikan, Universitas Esa Unggul
}

\section{Abstrak}

This study aims to determine the effect of implementation of cooperative learning model type teams games tournament (TGT) in science learning to motivation to learn fourth grade students of SDN Kelapa Dua 06 Pagi West Jakarta. The population in this research amounting to 52 people. The sample of this research consists of two groups, namely the experimental group of 26 people and the trial group of 27 people. Sampling is determined by purposive sampling technique. The results showed that: (1) the observation result during the study showed that the percentage of student activity increased by $66.67 \%$ to 93\%; (2) t-test results obtained p-value of $0.02(p<0.05)$ and tcount $>$ ttable ie $2.42>2.05$ which means reject H0. This shows that there is a positive influence of cooperative learning model of type teams games tournament (TGT) on the motivation to learn science of grade 4 students of SDN Kelapa Dua 06 Pagi Jakarta in the academic year 2016-2017.
\end{abstract}

\section{Keywords:}

Teams Games

Tournament (TGT),

Science Lesson, Learning Motivation

\section{Pendahuluan}

Pendidikan merupakan suatu hal yang penting bagi masyarakat. Setiap masyarakat mempunyai cita-cita tersendiri. Salah satu cara agar dapat mewujudkan cita-cita adalah dengan belajar. Belajar merupakan suatu kegiatan dimana para siswa memperoleh pengetahuan, baik dalam bentuk teori maupun praktek. Namun permasalahan dalam bidang pendidikan tak henti-hentinya muncul. Salah satu faktor dari permasalahan tersebut adalah rendahnya motivasi siswa dalam belajar. Motivasi terbagi atas dua unsur. Zahroh (2015:240), menjelaskan bahwa dua unsur tersebut yaitu motivasi intrinsik yang berasal dari dalam diri siswa dan motivasi ekstrinsik yang berasal dari luar diri siswa. Salah satu faktor penyebab rendahnya motivasi belajar yaitu motivasi ekstrinsik. Motivasi ekstrinsik dapat berupa pengajaran dari guru, kondisi kelas dalam pembelajaran maupun kegiatan yang menarik dalam pembelajaran. Guru mempunyai peran yang sangat penting dalam proses kegiatan belajar mengajar. Dalam menumbuhkan motivasi belajar siswa, guru dituntut untuk sekreatif mungkin dalam pengajarannya. Suprihatin (2015:81), mengatakan bahwa guru yang kreatif dalam pelaksanaan kegiatan belajar mengajar akan mengugah semangat belajar siswa sehingga siswa terdorong untuk melakukan suatu kegiatan pembelajaran.

Pengajaran guru yang menggunakan sistem pembelajaran konvensional dengan menggunakan metode ceramah saja akan membuat siswa merasa bosan. Seperti yang diungkapkan oleh Hamdayama (2016:99), bahwa guru yang menggunakan metode ceramah, kebanyakan tidak memiliki keterampilan yang diperlukan untuk menggunakan metode ceramah, sehingga siswa menjadi bosan. Pembelajaran konvensional tersebut adalah salah satu faktor yang umum dalam rendahnya motivasi siswa.

Dengan melakukan inovasi dalam pembelajaran, dapat meningkatkan keaktifan siswa di dalam kelas. Penggunaan model pembelajaran kooperatif tipe Teams Games Tournament (TGT) merupakan solusi atas permasalahan yang terjadi di dalam kelas. Hal ini didukung oleh pendapat Faizah (Syukur,dkk, 2014:311), untuk meningkatkan motivasi dan hasil belajar siswa dapat menggunakan model pembelajaranTGT karena TGT merupakan pembelajaran kooperatif yang efektif. Selaras dengan pendapat Slavin (Syukur, dkk, 2014:311),bahwa model pembelajaran TGT akan membuat siswa menikmati suasana permainan dan antusias dalam mengikuti kegiatan pembelajaran. 
IPA sebagai salah satu mata pelajaran di sekolah dapat memberikan peranan dan pengalaman bagi siswa. Hasil pembelajaran IPA pun dapat sangat dipengaruhi oleh motivasi dari siswa. Pembelajaran IPA dilakukan dengan berbagai upaya, yaitu salah satunya melalui peningkatan motivasi belajar. Menurut Vieyra (Syukur, dkk, 2014:311), model pembelajaran kooperatif termasuk pembelajaran yang paling efektif dalam pendidikan sains. Model pembelajaran kooperatif tipe teams games tournament lah yang digunakan sebagai penyelesaian atas permasalahan pada pembelajaran IPA.

Berdasarkan hal-hal tersebut tersebut, maka peneliti ingin mengetahui pengaruh model pembelajaran kooperatif tipe TGT dalam pembelajaran IPA terhadap motivasi belajar pada siswa kelas IV SDN Kelapa Dua 06 Pagi Jakarta Barat.

Priansa (2014:298), berpendapat bahwa model pembelajaran merupakan suatu bagian dari pembelajaran yang berbentuk kerangka konseptual yang sistematis dan digunakan dalam kegiatan pembelajaran, sehingga dapat mencapai tujuan pembelajaran yang efektif dan efisien. Pendapat lain dikemukakan oleh Hamdayama (2016:132), model pembelajaran adalah suatu pola atau langkah-langkah pembelajaran tertentu yang diterapkan agar tujuan atau kompetensi dari hasil belajar yang diharapkan akan cepat dan dapat dicapai dengan lebih efektif dan efisien. Kedua pendapat diatas juga serupa dengan pendapat Wisudawati dan Sulistyowati (2014:48), mengenai model pembelajaran adalah sebuah kerangka konseptual atau pola yang sistematis dalam mengorganisasikan pengalaman pembelajaran di dalam kelas sehingga mencapai tujuan pembelajaran yang diharapkan.

Pembelajaran kooperatif atau biasa disebut pembelajaran secara berkelompok merupakan pembelajaran yang erat kaitannya dengan berdiskusi. Syukur, dkk (2014:312), pembelajaran kooperatif merupakan strategi pembelajaran yang menggunakan kelompok-kelompok kecil dan memberi peluang bagi siswa untuk berinteraksi dengan siswa lainnya. Keberhasilan belajar dari kelompok bergantung pada kemampuan dan aktivitas anggota kelompok, baik secara individual maupun kelompok. Definisi model pembelajaran yang lain diungkapkan oleh Hamdayama (2016:145), menyatakan bahwa pembelajaran kooperatif adalah rangkaian kegiatan belajar yang dilakukan oleh siswa dalam kelompok-kelompok tertentu untuk mencapai tujuan pembelajaran yang telah dirumuskan. Sedangkan Slavin (2016:8), mengemukakan bahwa dalam pembelajaran kooperatif, para siswa akan duduk bersama dalam kelompok yang beranggotakan empat orang yang terdiri dari siswa yang berkemampuan heterogen guna menguasai materi yang diberikan oleh guru.

Dari beberapa pendapat diatas, dapat ditarik kesimpulan bahwa pembelajaran kooperatif adalah strategi pembelajaran yang didalamnya terdapat sekelompok kecildari siswa yang memiliki tingkat kemampuan yang berbeda, yang akan bekerja sama untuk mencapai tujuan dari suatu pembelajaran tertentu.

Pembelajaran kooperatif tipe teams game turnament(TGT) mempunyai definisi dikemukakan oleh Slavin (2016:163), bahwa kegiatan pembelajaran kooperatif teams game turnaments (TGT) sama seperti STAD, bedanya adalah TGT menggunakan turnamen akademik dan menggunakan kuis-kuis serta sistem skor kemajuan individu dimana para peserta didik berlomba sebagai wakil tim mereka dengan anggota tim yang lain yang kinerja akademiknya sebelumnya setara seperti mereka. Sedangkan Hamdayama (2016: 122), menjelaskan bahwa teams game turnament(TGT) adalah salah satu metode pembelajaran kooperatif yang melibatkan seluruh siswa tanpa harus ada perbedaan status, melibatkan peran siswa sebagai tutor sebaya, yang mengandung unsur permainan serta penguatan. Pendapat lain dikemukakan oleh Syukur, dkk (2014:313), bahwa secara umum, TGT hampir sama dengan STAD, hanya saja TGT menggunakan turnamen akademik maupun kuis dan sistem skor kemajuan individu.

Penjelasan di atas dapat disimpulkan bahwa teams games tournament (TGT) adalah salah satu tipe pembelajaran kooperatif dimana didalamnya terdapat komponen pembelajaran yang di kemas dalam bentuk permainan yang terdiri dari kelompok-kelompok siswa yang melakukan turnamen akademik maupun kuis.

Uno (2008:23), mengartikan sebuah motivasi belajar merupakan dorongan internal maupun eksternal pada siswa-siswa yang sedang belajar untuk mengadakan perubahan tingkah laku. Definisi lain muncul dari Zahroh (2015:238), motivasi belajar merupakan keinginan atau dorongan untuk belajar. Sedangkan menurut Priansa (2014:97), motivasi belajar peserta didik merupakan pendorong yang akan menggambarkan sikap dan perilaku peserta didik dalam belajar. Dari beberapa pendapat diatas dapat disimpulkan bahwa motivasi merupakan suatu dorongan yang dapat membuat seseorang untuk dapat mencapai suatu tujuan dalam belajar.

Motivasi belajar memiliki indikator keberhasilan, antara lain yaitu : (1) adanya hasrat dan keinginan berhasil; (2) adanya dorongan dan kebutuhan dalam belajar; (3) adanya harapan dan cita-cita masa depan; (4) adanya penghargaan dalam belajar; (5) adanya kegiatan yang menarik dalam belajar; (6) adanya lingkungan belajar yang kondusif, sehingga siswa dapat menyerap materi dengan baik. (Uno, 2008:23). 
Banyak faktor yang dapat mempengaruhi motivasi dalam belajar dan pembelajaran. Faktor tersebut dapat berasal dari diri pribadi siswa maupun lingkungan. Pada lingkungan, terdapat motif intrinsik dan ekstrinsik yang dapat mempengaruhi motivasi belajar siswa. lebih jauhnya Uno (2008:2934), mengungkapkan faktor-faktor yang dapat mempengaruhi motivasi belajar siswa. Jika dilihat berdasarkan dalam diri pribadi siswa, motif berprestasi merupakan faktor utama. Karena keinginan untuk berhasil pada suatu pembelajaran tertentu di kendalikan oleh diri pribadi siswa sendiri. Selanjutnya, selain faktor dari dalam diri pribadi siswa juga faktor lingkungan dapat berpengaruh pada motivasi belajar siswa. faktor lingkungan memiliki dua motif, yaitu motif intrinsik dan ekstrinsik. Motif intrinsik berasal dari dalam diri siswa seperti yang sudah dijelaskan di atas. Sedangkan motif ekstrinsik muncul karena adanya hukuman atau ganjaran yang berasal dari luar diri siswa.

Ilmu Pengetahuan Alam atau yang sering di sebut IPA merupakan pembelajaran yang menarik, karena didalamnya terdapat kaitannya dengan alam dan lingkungan yang ada disekitar kita. Seperti yang diungkapkan oleh Imamah (2012:32), pembelajaran IPA merupakan pembelajaran yang menyenangkan karena siswa dapat belajar melalui alam sekitar yang tentunya sudah tidak asing bagi mereka. Pendapat lain dikemukakan oleh Samatowa (2016:3), IPA atau science merupakan ilmu yang mempelajari tentang peristiwa-peristiwa alam yang ada dan terjadi di alam ini. Kedua pendapat tersebut di perkuat oleh Wisudawati dan Sulistyowati (2014:22), IPA merupakan rumpun ilmu yang mempelajari tentang fenomena alam yang faktual, baik berupa kenyataan atau kejadian dan hubungan sebab-akibatnya.

Dari pernyataan diatas dapat ditarik kesimpulan bahwa pelajaran IPA adalah ilmu yang mempelajari tentang fenomena atau peristiwa alam yang terjadi di alam semesta ini.

Siswa kelas IV Sekolah Dasar merupakan siswa yang baru saja memasuki kelompok kelas tinggi. Beralihnya dari kelas rendah menuju kelas tinggi menjadikan siswa kelas IV mengalami perubahan karakteristik. Adapun karakteristik siswa kelas tinggi antara lain yaitu:

"(a) siswa dapat memahami bahwa hukum dan aturan serta hasil kesepakatan sosial akan membantu memelihara kehidupan masyarakat yang harmonis; (b) berkembangnya perhatian untuk melaksanakan tugas sesuai dengan aturan yang berlaku; (c) berkembangnya perasaan empati secara tulus bagi mereka yang mengalami masalah sosial; (d) berkembangnya kepercayaan bahwa masyarakat memiliki kewajiban untuk membantu kebutuhan individu yang membutuhkan." (Surna dan Pandeirot, 2014:138).

Dari paparan karakteristik di atas, siswa yang menginjak usia 9-12 tahun atau siswa yang sedang duduk di bangku sekolah dasar di kelas tinggi memiliki karakteristik yang sudah mandiri dan tumbuhnya jiwa sosial serta dapat mentaati peraturan yang ada di masyarakat.

Pendapat lain diungkapkan oleh Priansa (2014:271), bahwa peserta didik yang berusia 6-12 tahun dalam tahap perkembangan sosial Erikson, anak ini sedang dalam fase keempat yaitu penguasaan dan rendah diri dimana anak sudah mampu berkomunikasi sehingga mereka dapat mulai membentuk kelompok. Pada usia ini, anak-anak sangat tertarik untuk belajar dan sangat sulit untuk berdiam diri. Pada masa ini, anak akan memperoleh pelajaran dengan mendapatkan suatu keyakinan bahwa mereka mampu menguasai masalah yang mereka hadapi. Namun apabila pada fase ini anak tidak berhasil melewatinya, maka kompetensi mereka akan digantikan dengan rasa rendah diri yang berdampak pada masa yang akan datang. Anak yang penuh rendah diri akan sulit untuk mengembangkan kompetensi dalam bidang yang penting.

Penjelasan lebih rinci di kemukakan oleh Desmita (2016:35), karakteristik anak usia 10-12 tahun berbeda dengan anak yang lebih muda dengan mereka. Anak-anak kelas tinggi atau anak kelas IV sampai VI SD sedang berada pada masa kanak-kanak akhir dimana mereka senang bermain, senang bergerak, senang bekerja dalam kelompok, dan senang merasakan atau melakukan secara langsung. Oleh karena itu guru seharusnya mengembangkan pembelajaran yang memiliki unsur permainan, mengusahakan siswa untuk aktif berpindah dan bergerak, bekerja atau belajar dalam kelompok, serta memberi kesempatan untuk terlibat langsung dalam pembelajaran.

Berdasarkan pernyataan diatas, dapat diketahui bahwa siswa SD kelas IV memiliki karakter seperti senang bekerjasama, rasa ingin tahu yang tinggi, mulai hidup dengan kemandirian, dan senang dengan permainan. Dilihat dari karakter siswa tersebut, metode Teams Games Tournament (TGT) cocok dilakukan di SD kelas IV karena siswa SD kelas IV senang dengan permainan dan suka bekerjasama.

Metode penelitian eksperimen adalah jenis penelitian yang masuk dalam kategori kuantitatif. Lebih tepatnya Sugiyono (2013:72), menjelaskan bahwa metode penelitian eksperimen berarti metode penelitian yang digunakan untuk mencari pengaruh perlakuan tertentu terhadap yang lain dalam kondisi yang terkendalikan. Dalam penelitian eksperimen, terdapat perlakuan (treatment) yang dilakukan dalam kelas eksperimen.

Desain penelitian yang digunakan adalah Pre-Experimental Designs jenis One-Group PretestPosttest Design. Desain ini dipergunakan karena penelitian ini berusaha untuk menemukan ada tidaknya 
pengaruh antara model pembelajaran kooperatif tipe TGT dalam pembelajaran IPA terhadap motivasi belajar siswa kelas IV SDN Kelapa Dua 06 Pagi Jakarta Barat. Sugiyono (2013:74), menerangkan bahwa pada desain penelitian yang menggunakan one-group pretest-posttest design, kelompok eksperimen sebelumnya diberi pretest dan setelah mendapat perlakuan diberikan posttest. Dengan demikian hasil perlakuan dapat diketahui lebih akurat, karena dapat membandingkan dengan keadaan sebelum diberi perlakuan. mengungkapkan bahwa penelitian ini bertujuan untuk mencari pengaruh dari variabel bebas terhadap variabel terikat dari suatu penelitian.

Populasi dalam pandangan Sugiyono (2013:80), merupakan wilayah generalisasi yang terdiri atas obyek/subyek yang mempunyai karakteristik dan kualitas tertentu yang dipelajari oleh peneliti untuk kemudian di tarik kesimpulannya. Berdasarkan pendapat tersebut diatas dapat disimpulkan populasi adalah keseluruhan subyek penelitian yang memiliki ciri-ciri yang akan diteliti. Populasi dari penelitian ini adalah seluruh siswa kelas IV SDN Kelapa Dua 06 Pagi Jakarta Barat Tahun pelajaran 2016/ 2017 yang berjumlah 52 orang.

Sugiyono (2013:10), berpendapat mengenai sampel adalah sebagian atau wakil dan karakteristik dari jumlah populasi yang diteliti agar sampel yang diambil mewakili data penelitian, maka perlu adanya perhitungan besar kecilnya populasi. Dalam pemilihan sampel, Sugiyono (2013:81), menjelaskan bahwa seharusnya dalam pemilihan sampel dari populasi harus betul-betul representatif (mewakili).

Pada penelitian ini teknik pengambilan sampel yang digunakan adalah nonprobability sampling bentuk sampling purposive. Sampling purposive teknik pelaksanaanya dilakukan dengan menentukan sampel dengan pertimbangan tertentu. Sampel dalam penelitian ini adalah siswa kelas 4B yang berjumlah 26 orang.

Sugiyono (2013: 147), menjelaskan bahwa yang dimaksudkan dengan analisis data adalah mengelompokkan data berdasarkan variabel dan jenis responden, menyajikan data tiap variabel yang diteliti, melakukan perhitungan untuk menjawab rumusan masalah, dan melakukan perhitungan untuk menguji hipotesis yang telah diajukan. Analisis data yang digunakan pada penelitian ini adalah analisis data kuantitatif.

Selama kegiatan penelitian yang dilakukan sebanyak dua kali pertemuan, motivasi belajar siswa selalu diukur pada setiap pertemuan yaitu dengan membagikan angket motivasi belajar pada akhir pembelajaran. Hasil pengisian angket pada setiap kali tersebut kemudian dijumlahkan didapatlah skor motivasi belajar masing-masing siswa pada setiap pertemuan. Skor yang diperoleh siswa ini masih berupa skor mentah (raw skor) dan belum dapat dikatakan sebagai skor yang baku, untuk itu perlu dilakukan pengkonversian skor mentah menjadi skor akhir. Setelah skor mentah motivasi belajar IPA siswa pada setiap pertemuan dikonversikan menjadi skor akhir, maka langkah selanjutnya adalah skor akhir yang sudah didapat kemudian diambil rata-ratanya, hasil rata-rata inilah yang nantinya akan digunakan untuk perhitungan selanjutnya.

Setelah skor akhir motivasi belajar siswa telah diperoleh, maka langkah selanjutnya adalah mengkategorikan data kedalam tiga kategori yaitu tinggi, sedang dan rendah.Pengkategorisasian ini dilakukan karena motivasi belajar merupakan ciri data ordinal, selain itu juga untuk memudahkan dalam perhitungan pada pengujian hipotesis. Adapun kategorisasi motivasi belajar IPA ini menggunakan pengolahan data dengan pendekatan penilaian acuan norma (PAN). Oleh karena itu pengkategorian motivasi belajar IPA siswa didapat berdasarkan skor akhir yang diperoleh. Untuk melakukan kategorisasi berdasarkan pendekatan PAN ini menggunakan rumus simpangan baku (SD) dan nilai baku atau angka skala sebagai alat bantu praktis.

Data yang diperoleh dari peneitian ini adalah data motivasi melalui hasil angket sebelum diberi perlakuan dan sesudah diberi perlakuan. Hal ini dilakukan untuk menentukan kelompok motivasi belajar tinggi, sedang dan rendah. Uji prasyarat analisis dilakukan dengan uji normalitas, uji homogenitas dan uji signifikansi. Uji normalitas data dilakukan menggunakan uji Liliefors, sedangkan uji homogenitas menggunakan uji Bartlett dan uji signifikansi menggunakan korelasi product moment secara praktis. Selanjutnya pengujian hipotesis dilakukan untuk mengetahui apakah model pembelajaran kooperatif tipe teams games tournament lebih baik dibandingkan dengan pembelajaran konvensional untuk meningkatkan motivasi belajar IPA dengan menggunakan uji-t untuk dua kelompok data dari satu kelompok sampel (berpasangan).

\section{Metode Penelitian}

Penelitian ini termasuk penelitian eksperimen semu karena tidak semua variabel dapat dikontrol secara ketat. Tempat pelaksanaan penelitian ini adalah di SDN Kelapa Dua 06 Pagi Jakarta Barat. Populasi dalam penelitian ini berjumlah 52 orang. Sampel penelitian ini terdiri dari dua kelompok, yaitu kelompok eksperimen sebanyak 26 orang dan kelompok uji coba 27 orang. Pengambilan sampel ditentukan dengan 
teknik purposive sampling. Teknik ini dilakukan dengan mencampur subjeksubjek di dalam populasi sehingga semua subjek dianggap sama dan mendapat hak yang sama untuk memperoleh kesempatan dipilih menjadi anggota sampel (Agung, 2010).

Variabel bebas dalam penelitian ini adalah model TGT, sedangkan variabel terikatnya adalah motivasi belajar. Pengumpulan data dalam penelitian ini menggunakan metode non tes. Data yang dikumpulkan adalah data skor motivasi belajar siswa. Instrumen yang digunakan adalah angket motivasi belajar yang dibuat berdasarkan indikator motivasi belajar. Instrumen yang telah disusun diuji coba untuk mendapatkan gambaran tentang kelayakan instrumen agar dapat dipergunakan sebagai instrumen penelitian.

Metode analisis data dalam penelitian ini menggunakan metode analisis statistik deskriptif dan statistik inferensial. Analisis deskriptif yang digunakan dalam penelitian ini yaitu mean, median, modus, varian dan standar deviasi. Teknik penyajian data hasil perhitungan mean, median dan modus disajikan ke dalam kurva poligon. Teknik analisis data yang digunakan untuk menguji hipotesis penelitian ini adalah statistik inferensial uji-t tidak berkorelasi (indenpendent t-test) dengan rumus polled varians. Sebelum dilakukan hipotesis, dilakukan uji prasyarat, yaitu uji normalitas dan uji homogenitas. Hipotesis dalam peneltian ini adalah terdapat perbedaan motivasi belajar IPA antara kelompok siswa yang dibelajarkan dengan model TGT dengan kelompok siswa yang dibelajarkan dengan model pembelajaran konvensional pada siswa kelas IV SDN Kelapa Dua 06 Pagi Jakarta Barat.

\section{Hasil Dan Pembahasan}

Data motivasi belajar diambil dari kelas eksperimen yang berjumlah 26 siswa. Data hasil angket motivasi belajar digunakan untuk mengkategorisasikan siswa yang memiliki motivasi belajar tinggi, sedang maupun rendah. Data yang diperoleh kemudian dianalisis dengan menggunakan program SPSS versi 23.0, dengan taraf signifikansi 0,05 , artinya bahwa kemungkinan penolakan hipotesis yang benar adalah 5 diantara 100. Dengan kata lain derajat kepercayaan terhadap kebenaran hipotesis adalah sebesar $95 \%$.

Data observasi mengenai keadaan kelas ketika penelitian berlangsung. Observasi dilakukan dengan melihat aktivitas guru dan siswa di dalam kelas. Observasi aktivitas guru sebelum perlakuan memiliki 6 aspek dan 20 butir item yang akan diamati. Dari 20 butir hal yang diamati, guru tidak melakukan 4 hal. Karena pada pembelajaran kali ini guru tidak menggunakan media pembelajaran. Selain itu juga guru tidak tepat waktu dalam menyampaikan materi. Hasil observasi keaktifan guru dengan menggunakan model pembelajaran konvensional atau dalam melakukan pembelajaran sebelum perlakuan adalah $80 \%$.

Observasi aktivitas guru sesudah perlakuan memiliki 5 aspek yang akan diamati. Untuk lebih lengkapnya mengenai aspek dan butir setiap aspek dapat dilihat di lampiran. Dari 28 butir aspek yang diamati, guru telah melakukan 27 butir aspek. 1 butir aspek tidak dilakukan karena guru tidak memberikan contoh soal sesuai materi, tetapi langsung dijelaskan dengan memberikan siswa sajian mengenai materi. Berdasarkan hasil observasi yang telah dilakukan, tingkat keaktifan guru dalam mengajar menggunakan model pembelajaran teams games tournament pada penelitian ini meningkat menjadi sebesar $96 \%$.

Selanjutnya observasi mengenai aktivitas siswa di dalam kelas ketika pembelajaran menggunakan pembelajaran konvensional berlangsung. Lembar observasi aktivitas siswa sebelum perlakuan memiliki 6 aspek yang akan diamati. Dari 6 aspek tersebut terdapat 60 butir item yang akan diamati selanjutnya. Berdasarkan pengamatan yang telah dilakukan, siswa memperoleh 40 poin dari jumlah poin 60. Hasil observasi mengenai aktivitas siswa di dalam kelas ketika pembelajaran menggunakan pembelajaran konvensional adalah sebesar $66,67 \%$. Selanjutnya dilakukan observasi siswa setelah mendapat perlakuan. Lembar observasi aktivitas siswa memiliki 4 pilihan sesuai dengan kriteria yang ada. Dari 20 butir aspek yang diamati dengan jumlah poin 80 , hasil observasi aktivitas siswa memperoleh 74 poin. Persentase tingkat keaktifan siswa dengan menggunakan model pembelajaran kooperatif tipe teams games tournament (TGT) meningkat menjadi 93\%.

Wawancara dilakukan setelah pembelajaran IPA dengan menggunakan model pembelajaran teams games tournament. Narasumber berasal dari 4 orang siswa yang memiliki kecerdasan yang berbeda-beda. Berdasarkan hasil wawancara, dapat dikatakan mereka mengalami perbedaan motivasi sebelum dan sesudah belajar IPA menggunakan model pembelajaran kooperatif tipe TGT. Terdapat respon yang positif mengenai penggunaan model pembelajaran kooperatif tipe TGT terhadap motivasi belajar IPA siswa kelas IV SDN Kelapa Dua 06 Pagi Jakarta.

\section{Tabel 1}


Pengkonversian Skor Mentah Menjadi Skor Akhir Pretest

\begin{tabular}{|c|c|c|}
\hline No. Responden & Skor Mentah & Skor Akhir \\
\hline 1 & 72 & 96 \\
\hline 2 & 70 & 93,33 \\
\hline 3 & 69 & 92 \\
\hline 4 & 72 & 96 \\
\hline 5 & 69 & 92 \\
\hline 6 & 70 & 93,33 \\
\hline 7 & 67 & 89,33 \\
\hline 8 & 61 & 81,33 \\
\hline 9 & 71 & 94,67 \\
\hline 10 & 65 & 86,67 \\
\hline 11 & 70 & 93,33 \\
\hline 12 & 72 & 96 \\
\hline 13 & 69 & 92 \\
\hline 14 & 74 & 98,67 \\
\hline 15 & 75 & 100 \\
\hline 16 & 63 & 84 \\
\hline 17 & 69 & 92 \\
\hline 18 & 64 & 85,33 \\
\hline 19 & 68 & 90,67 \\
\hline 20 & 69 & 92 \\
\hline 21 & 66 & 88 \\
\hline 22 & 68 & 90,67 \\
\hline 23 & 68 & 90,67 \\
\hline 24 & 73 & 97,33 \\
\hline 25 & 71 & 94,67 \\
\hline 26 & 68 & 90,67 \\
\hline Total skor & 1793 & 2296 \\
\hline Rata-rata & 68,9615 & 91,84 \\
\hline
\end{tabular}

Hasil penelitian di dapat melalui angket pretest dan posttest. Skor motivasi belajar siswa yang di dapat dari setiap pertemuan merupakan skor mentah. Agar skor dapat dikatakan baku, maka skor mentah dikonversikan menjadi skor akhir. Selanjutnya skor akhir yang didapat akan diambil rata-ratanya. Adapun hasil perhitungannya dapat dilihat pada tabel 1 berikut ini.

Berdasarkan tabel 1, dapat dilihat bahwa jumlah skor mentah siswa pada pretest sebesar 1793 dan skor akhir siswa adalah 2296 serta rata-rata skor pretest motivasi belajar IPA adalah 91,84 dari 26 siswa.

Tabel 2

Pengkonversian Skor Mentah Menjadi Skor Akhir Posttest

\begin{tabular}{ccc}
\hline No. Responden & $\begin{array}{c}\text { Skor } \\
\text { Mentah }\end{array}$ & Skor Akhir \\
\hline 1 & 73 & 97,33 \\
2 & 74 & 98,67 \\
3 & 73 & 97,33 \\
4 & 67 & 89,33 \\
5 & 69 & 92 \\
6 & 71 & 94,67 \\
7 & 69 & 92 \\
8 & 62 & 82,67 \\
9 & 72 & 96 \\
10 & 67 & 89,33 \\
11 & 73 & 97,33 \\
\hline
\end{tabular}




\begin{tabular}{ccc}
\hline 12 & 75 & 100 \\
13 & 72 & 96 \\
14 & 75 & 100 \\
15 & 75 & 100 \\
16 & 63 & 84 \\
17 & 71 & 94,67 \\
18 & 65 & 86,67 \\
19 & 64 & 85,33 \\
20 & 70 & 93,33 \\
21 & 68 & 90,67 \\
22 & 65 & 86,67 \\
23 & 70 & 93,33 \\
24 & 74 & 98,67 \\
25 & 74 & 98,67 \\
26 & 69 & 92 \\
Total skor & $\mathbf{1 8 2 0}$ & $\mathbf{2 4 2 6 , 6 7}$ \\
Rata-rata & $\mathbf{7 0}$ & $\mathbf{9 3 , 3 3}$ \\
\hline
\end{tabular}

Pada tabel 2, dapat dilihat bahwa jumlah skor mentah siswa 1820, skor akhir posttest motivasi belajar IPA siswa sebesar 2426,67 dan rata-rata skornya adalah 93,33. Dengan begitu, hasil skor motivasi siswa meningkat sebanyak 24,37 atau rata-rata peningkatan skor akhir siswa adalah 0,93 setelah diterapkannya model pembelajaran kooperatif tipe TGT di dalam kelas. Berarti terdapat pengaruh penggunaan model pembelajaran kooperatif tipe teams games tournament terhadap motivasi belajar IPA siswa di kelas IV SDN Kelapa Dua 06 Pagi Jakarta sebesar 1,48\%.

Setelah skor akhir motivasi belajar siswa telah diperoleh, maka langkah selanjutnya adalah mengkategorikan data kedalam tiga kategori yaitu tinggi, sedang dan rendah. Kategorisasi motivasi belajar IPA ini menggunakan pengolahan data dengan pendekatan penilaian acuan norma (PAN). Setelah melakukan perhitungan, diperoleh nilai mean pada skor pretest motivasi belajar siswa 68,96 yang berarti bahwa rata-rata siswa masuk pada kategori motivasi sedang. Nilai simpangan baku 3,30. Apabila skor siswa melebihi 72,26 maka siswa termasuk dalam kategori motivasi tinggi, apabila skor siswa kurang dari 72,26 lebih dari 65,65 maka siswa masuk dalam kategori motivasi sedang dan apabila skor siswa kurang dari 65,65 maka siswa masuk kedalam kategori motivasi belajar rendah.

Sebelum perlakuan, siswa yang masuk dalam kategori motivasi tinggi sebanyak 3 orang (12\%), siswa yang masuk dalam kategori motivasi sedang sebanyak 19 orang (73\%) dan siswa yang masuk dalam kategori motivasi rendah sebanyak 4 orang (15\%), sedangkan setalah perlakuan, diketahui rerata dari skor mentah siswa adalah 67,40 menggambarkan bahwa rata-rata siswa memiliki tingkat motivasi yang sedang. Nilai simpangan baku 3,91 serta klasifikasi siswa yang memiliki motivasi tinggi adalah apabila skor motivasi siswa lebih dari 71,32, klasifikasi siswa yang memiliki motivasi tinggi apabila skor motivasi siswa kurang dari sama dengan 71,32 atau lebih dari sama dengan 63,48 dan apabila skor siswa kurang dari 63,48 maka klasifikasi motivasi belajar siswa masuk pada kategori rendah. Lebih lengkap dapat dilihat pada tabel 3.

Tabel 3

Kategorisasi Skor Motivasi Belajar IPA Siswa Sebelum Perlakuan

\begin{tabular}{|c|c|c|c|c|c|}
\hline M+1SD & & \multicolumn{2}{|c|}{ M-1SD } & Mean & SD \\
\hline 72,26 & & \multicolumn{2}{|c|}{65,65} & 68,96 & 3,30 \\
\hline $\begin{array}{c}\text { No } \\
\text { Resp. }\end{array}$ & $\begin{array}{c}\text { Skor } \\
\text { Mentah }\end{array}$ & Klasifikasi & $\begin{array}{c}\text { No } \\
\text { Resp. }\end{array}$ & $\begin{array}{c}\text { Skor } \\
\text { Mentah }\end{array}$ & Klasifikasi \\
\hline 1 & 72 & Sedang & 14 & 74 & Tinggi \\
\hline 2 & 70 & Sedang & 15 & 75 & Tinggi \\
\hline 3 & 69 & Sedang & 16 & 63 & Rendah \\
\hline 4 & 72 & Sedang & 17 & 69 & Sedang \\
\hline 5 & 69 & Sedang & 18 & 64 & Rendah \\
\hline 6 & 70 & Sedang & 19 & 68 & Sedang \\
\hline
\end{tabular}




\begin{tabular}{clllll}
\hline 7 & 67 & Sedang & 20 & 69 & Sedang \\
8 & 61 & Rendah & 21 & 66 & Sedang \\
9 & 71 & Sedang & 22 & 68 & Sedang \\
10 & 65 & Rendah & 23 & 68 & Sedang \\
11 & 70 & Sedang & 24 & 73 & Tinggi \\
12 & 72 & Sedang & 25 & 71 & Sedang \\
13 & 69 & Sedang & 26 & 68 & Sedang \\
\hline
\end{tabular}

Setelah perlakuan, siswa yang masuk dalam kategori motivasi tinggi meningkat menjadi 10 orang (38\%), yang masuk dalam kategori motivasi sedang menurun menjadi 14 orang (54\%) dan siswa yang masuk dalam kategori motivasi rendah menurun menjadi 2 orang (8\%). Lebih lengkapnya dapat dilihat pada tabel 4 .

Tabel 4

Kategorisasi Skor Motivasi Belajar IPA Siswa Sesudah Perlakuan

\begin{tabular}{|c|c|c|c|c|c|}
\hline \multicolumn{2}{|c|}{ M+1SD } & \multicolumn{2}{|c|}{ M-1SD } & \multirow{2}{*}{$\begin{array}{l}\text { Mean } \\
67,40\end{array}$} & \multirow{2}{*}{$\begin{array}{c}\text { SD } \\
3,91\end{array}$} \\
\hline \multicolumn{2}{|c|}{71,32} & \multicolumn{2}{|c|}{63,48} & & \\
\hline $\begin{array}{c}\text { No } \\
\text { Resp. }\end{array}$ & $\begin{array}{c}\text { Skor } \\
\text { Mentah }\end{array}$ & Klasifikasi & $\begin{array}{c}\text { No } \\
\text { Resp. }\end{array}$ & $\begin{array}{c}\text { Skor } \\
\text { Mentah }\end{array}$ & Klasifikasi \\
\hline 1 & 73 & Tinggi & 14 & 75 & Tinggi \\
\hline 2 & 74 & Tinggi & 15 & 75 & Tinggi \\
\hline 3 & 73 & Sedang & 16 & 63 & Rendah \\
\hline 4 & 67 & Sedang & 17 & 71 & Sedang \\
\hline 5 & 69 & Sedang & 18 & 65 & Sedang \\
\hline 6 & 71 & Sedang & 19 & 64 & Sedang \\
\hline 7 & 69 & Sedang & 20 & 70 & Sedang \\
\hline 8 & 62 & Rendah & 21 & 68 & Sedang \\
\hline 9 & 72 & Tinggi & 22 & 65 & Sedang \\
\hline 10 & 67 & Sedang & 23 & 70 & Sedang \\
\hline 11 & 73 & Tinggi & 24 & 74 & Tinggi \\
\hline 12 & 75 & Tinggi & 25 & 74 & Tinggi \\
\hline 13 & 72 & Tinggi & 26 & 69 & Sedang \\
\hline
\end{tabular}

Uji validitas menggunakan korelasi product moment dimana jumlah item pada instrumen pretest maupun posttest sebanyak 15 butir. Adapun kriteria kevalidan instrumen penelitian ini jika $r>0,30$ maka butir instrumen tersebut dinyatakan valid. Namun sebaliknya jika $r<0,30$ maka butir instrumen tersebut tidak valid. Selain itu, dapat juga dibandingkan nilai $r_{\text {hitung }}$ dengan $r_{\text {tabel. }}$. Jika $r_{\text {hitung }}>r_{\text {tabel }}$ maka instrumen dinyatakan valid dan sebaliknya. Nilai $r_{\text {tabel }}$ dengan df 25 dan taraf signifikansi sebesar 5\% adalah 0,39. Nilai $r_{\text {hitung }}$ dilihat pada kolom Corrected Item-Total Correlation.

Pada tabel 5 pada kolom Corrected Item-Total Correlation diperoleh data bahwa item 6 memiliki nilai $r$ hitung 0,39 dan item 10 memiliki nilai $r$ hitung 0,36. Jika dilihat berdasarkan kriteria validitas $\mathrm{r}_{\text {hitung }}$ $>r_{\text {tabel, dengan nilai }} r_{\text {tabel }}$ 0,39 maka kedua item tersebut dapat dinyatakan tidak valid. Agar item dapat digunakan maka kriteria validitas akan mengacu kepada $r>0,30$, sehingga seluruh item pretest pada penelitian ini valid dan dapat digunakan. Pada tabel 6, seluruh item posttest memiliki nilai $r_{\text {hitung }}>r_{\text {tabel }}(r$ $>0,36)$ maka seluruh item dinyatakan valid dan layak untuk digunakan. 
Tabel 5

Hasil Perhitungan Validitas Pretest

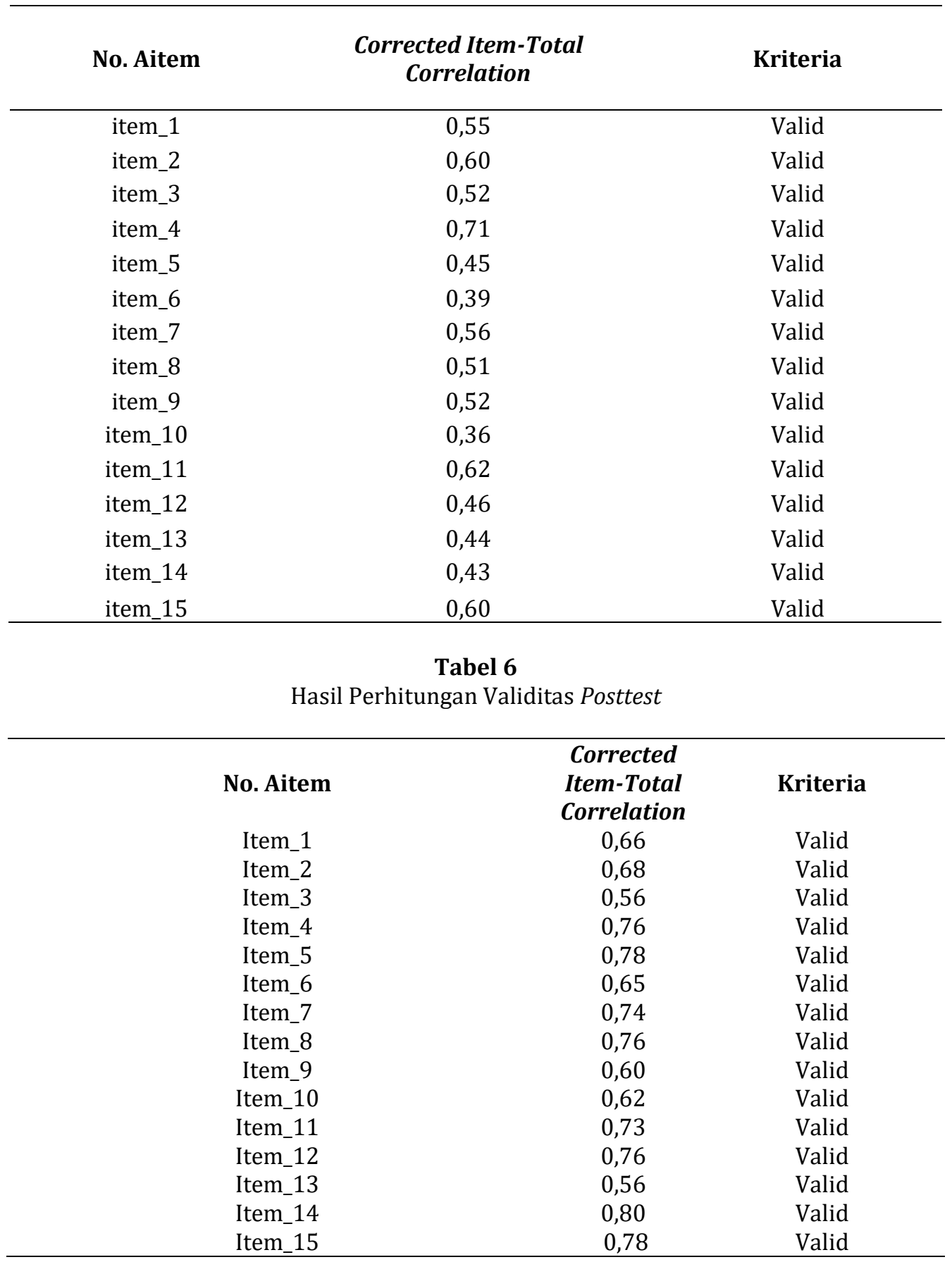

Nilai reliabilitas instrumen dapat diketahui dengan membandingkan nilai $r_{\text {hitung }}$ dengan $r_{\text {tabel. }}$ Jika $r_{\text {hitung }} \geq r_{\text {tabel }}$ maka reliabel, jika $r_{\text {hitung }}<r_{\text {tabel }}$ maka tidak reliabel. Selain itu terdapat kriteria nilai reliabilitas menggunakan Alfa Cronbach. Jika nilai $\mathrm{r}<0,60$ maka instrumen tidak reliabel, jika nilai $\mathrm{r}>0,60$ maka instrumen dapat dikatakan reliabel. Nilai $r_{\text {tabel }}$ dengan df 25 dan taraf signifikansi sebesar 5\% adalah 0,39. Nilai $r_{\text {hitung }}$ dapat dilihat pada kolom Cronbach's Alpha pada tabel 7 dan 8.

Dari tabel 7 diperoleh $r_{\text {hitung }} 0,86$ lebih besar dari 0,39. Hal ini berarti $r_{\text {hitung }}>r_{\text {tabel }}$, sehingga instrumen pretest dapat dikatakan reliabel. Selanjutnya hasil perhitungan reliabilitas posttest dapat dilihat pada tabel 8.

Dari tabel 8 diperoleh $r_{\text {hitung }} 0,94$ lebih besar dari 0,39. Hal ini berarti $r_{\text {hitung }}>r_{\text {tabel }}$, sehingga instrumen pretest dapat dikatakan reliabel. 
Tabel 7

Hasil Perhitungan Reliabilitas Pretest

\begin{tabular}{cc}
\hline Cronbach's Alpha & Nof Items \\
\hline \multicolumn{2}{c}{$\begin{array}{c}\text { Tabel 8 } \\
\text { Tasil Perhitungan Reliabilitas Posttest }\end{array}$} \\
\hline Cronbach's Alpha & 15 \\
\hline 0,94 & N of Items \\
\hline
\end{tabular}

Uji normalitas pada penelitian ini digunakan sebagai prasyarat untuk uji t. Dalam penelitian ini data harus berdistribusi normal, sebab uji t dapat dilakukan apabila data berdistribusi normal. Suatu distribusi dikatakan normal jika taraf signifikansinya $>0,05$, sedangkan jika taraf signifikansinya $<0,05$ maka data tidak berdistribusi normal. Berikut ini merupakan hasil perhitungan uji normalitas pada angket pretest dan posttest motivasi belajar dapat dilihat pada tabel 9.

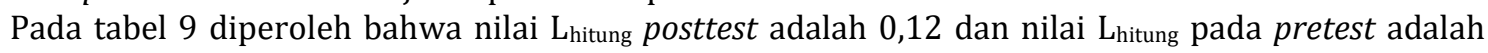
0,15. Ltabel dengan df 26 dan taraf signifikansi $5 \%$ adalah 0,17. Maka nilai $L_{\text {hitung }}$ posttest kurang dari $\mathrm{L}_{\text {tabel }}$ $(0,12<0,17)$ dan nilai $L_{h i t u n g}$ pretest kurang dari $\mathrm{L}_{\text {tabel }}(0,15<0,17)$, sehingga $\mathrm{H}_{0}$ diterima atau data berdistribusi normal. Dilihat dari nilai sig pada angket pretest adalah $0,11(0,11>0,05)$ dan pada angket posttest adalah $0,20(0,20>0,05)$, sehingga dapat disimpulkan bahwa hasil perhitungan uji normalitas dari kedua data penelitian ini adalah lebih dari $0,05(\mathrm{p}>0,05)$, yang artinya data tersebut berdistribusi normal.

Tabel 9

Uji Normalitas Data Pretest dan Posttest

\begin{tabular}{|c|c|c|c|c|c|c|}
\hline \multicolumn{6}{|c|}{ Tests of Normality } & \\
\hline Faktor & Statistic & Df & Sig. & Statistic & Df & Sig. \\
\hline Motivasi Belajar IPA Posttest & 12 & 26 & $20^{*}$ & ,93 & 26 & 09 \\
\hline Pretest & ,15 & 26 & 11 & ,97 & 26 & 61 \\
\hline
\end{tabular}

Berdasarkan gambar 1 dan 2, kurva normalitas membentuk pola distribusi normal, sehingga asumsi normalitas terpenuhi. Selain melihat histogram normalitas, bukti yang menunjukkan bahwa data normal dapat dilihat melalui diagram normal Q-Q Plot seperti pada gambar 3 dan 4 .

Jika dilihat dari bentuk persebaran data pada gambar 3, plot-plot tersebar dekat dengan garis diagonal dan mengikuti arah garis lurus. Maka pola tersebut berdistribusi normal. Pola yang terdapat pada gambar 4 menunjukkan hasil yang sama dengan gambar 3, bahwa plot-plot tersebar dekat dan mengikuti garis diagonal. Dengan begitu, data pretest maupun posttest berdistribusi normal. 


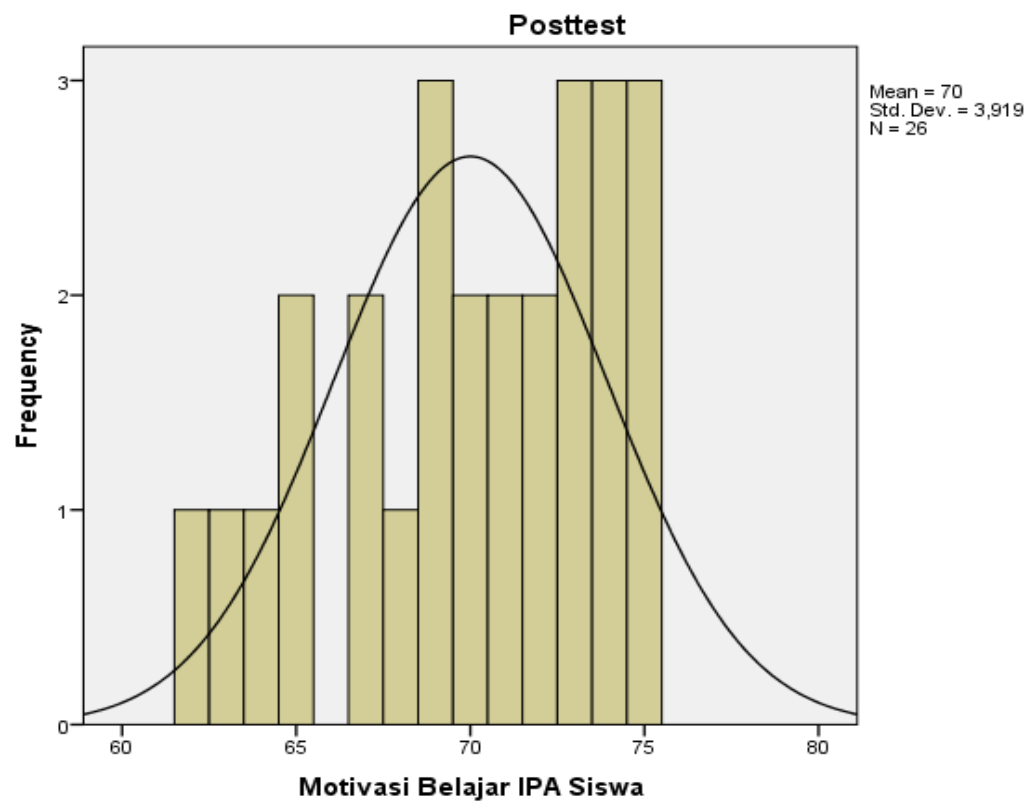

Gambar 1.

Histogram Normalitas Posttest

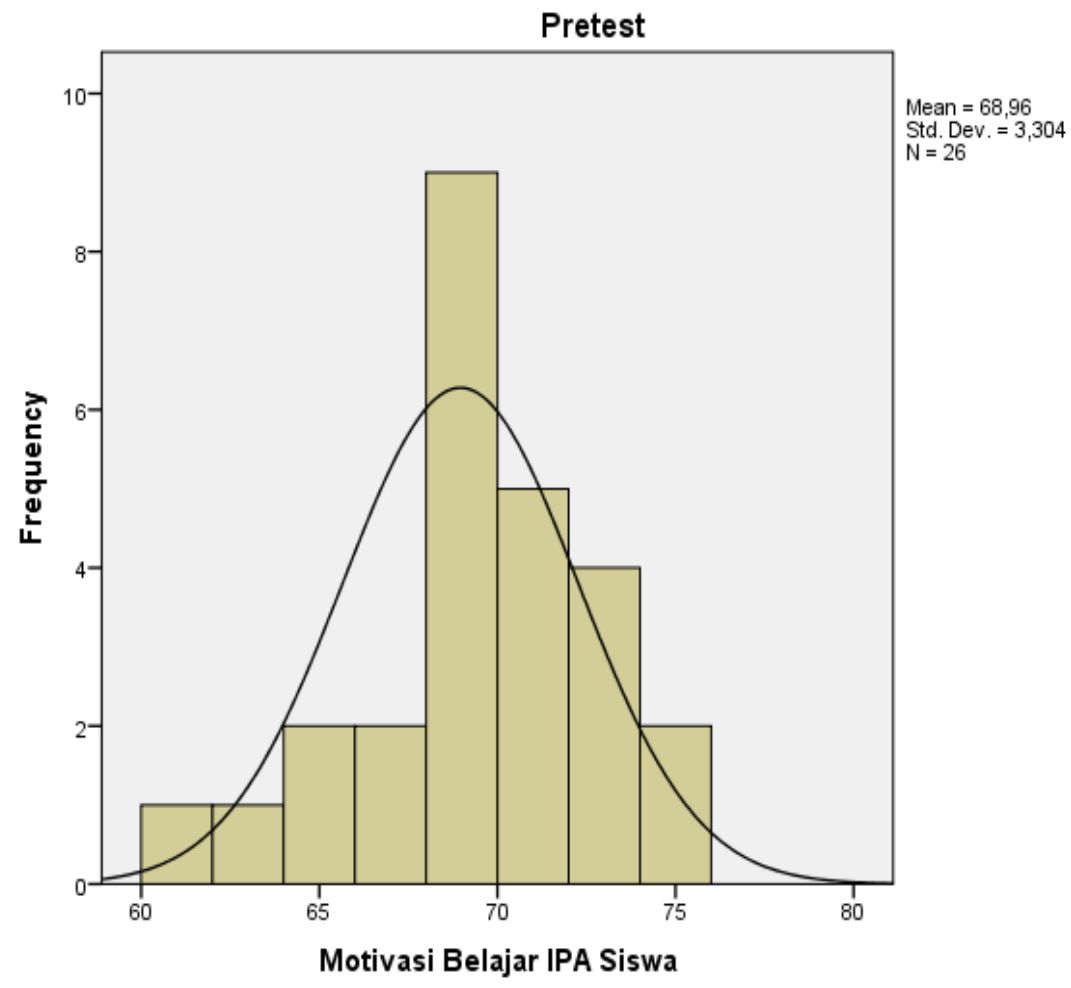

Gambar 2.

Histogram Normalitas Pretest 


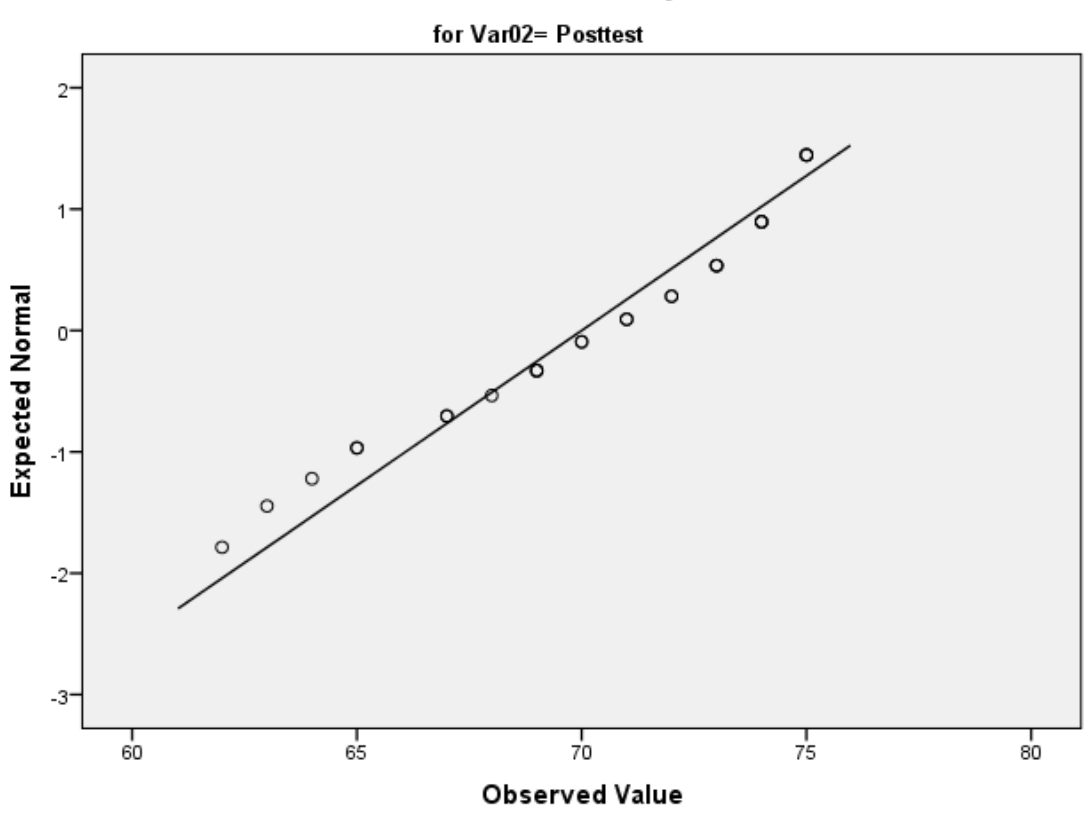

Gambar 3.

Diagram Normal Q-Q Plot Posttest

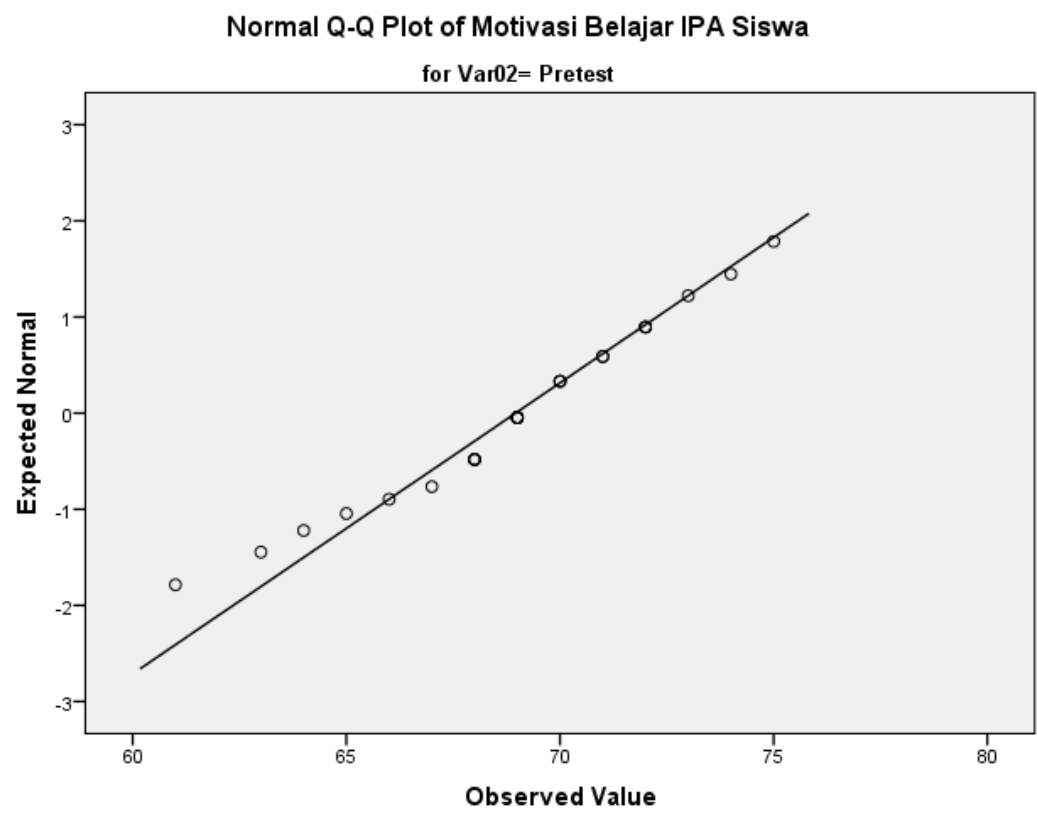

Gambar. 4

Diagram Normal Q-Q Plot Pretest

Uji homogenitas merupakan pengujian yang dilakukan untuk mengetahui apakah data dari sampel penelitian mempunyai varians yang sama atau tidak. Untuk melakukan uji t, data terlebih dahulu harus homogen. Suatu distribusi dikatakan homogen apabila taraf signifikansinya $>0,05$, sedangkan apabila taraf signifikansinya $<0,05$ maka dapat dikatakan data tersebut tidak berdistribusi homogen. Data yang akan di uji homogenitasnya adalah data pretest dan posttest motivasi belajar siswa dari 26 siswa. Adapun hasil perhitungannya dapat dilihat pada tabel 10. 
Tabel 10

Uji Homogenitas Data Pretest dan Posttest

\begin{tabular}{cccc}
\hline Levene Statistic & df1 & df2 & Sig. \\
\hline 1,78 & 1 & 50 &, 18 \\
\hline
\end{tabular}

Jika dilihat dari tabel diatas, dapat diketahui bahwa nilai signifikansinya adalah 0,18. Karena nilai signifikansi lebih besar dari 0,05, yakni 0,18 > 0,05 sehingga data pretest dan posttest tesebut dapat dikatakan homogen.

Uji signifikansi dilakukan dengan membandingkan nilai $r$ hitung dengan $r$ tabel. Ketentuannya bila $\mathrm{r}$ hitung $<\mathrm{r}$ tabel, maka $\mathrm{H}_{0}$ diterima. Tetapi sebaliknya bila $\mathrm{r}$ hitung $>\mathrm{r}$ tabel maka Ha diterima. Dengan df 24 dan taraf signifikansi 5\% diperoleh nilai $r$ tabel 0,40. Berikut ini dapat dilihat $r$ hitung dalam kolom Correlation pada tabel 11.

Dilihat dari tabel 11 bahwa diperoleh $r$ hitung 0,83. Berdasarkan ketentuannya, $r$ hitung $>r$ tabel atau 0,83 > 0,40 maka Ha diterima.

Setelah melakukan serangkaian pengujian data, maka pengujian hipotesis dilakukan. Pengujian hipotesis menggunakan uji-t. Uji hipotesis digunakan untuk mengetahui ada atau tidaknya pengaruh model pembelajaran kooperatif tipe TGT terhadap motivasi belajar IPA siswa. Adapun kriteria pengujian hipotesis dengan uji-t apabila nilai signifikansi $<0,05$ maka $\mathrm{H}_{0}$ ditolak, sedangkan apabila nilai signifikansi $>0,05$ maka $\mathrm{H}_{0}$ diterima. Selain itu juga terdapat kriteria pengujian hipotesis untuk satu pihak kanan, yaitu tolak $\mathrm{H}_{0}$, jika $\mathrm{t}_{\text {hitung }}>\mathrm{t}_{\text {tabel }}$ dan terima $\mathrm{H}_{0}$, jika $\mathrm{t}_{\text {hitung }}<\mathrm{t}_{\text {tabel }}$.

Dari hasil uji hipotesis menggunakan uji-t, diperoleh $t_{\text {hitung }}$ sebesar 2,42 dan $t_{\text {tabel }}$ sebesar 1,71. Dengan demikian $\mathrm{t}$ hitung $>\mathrm{t}$ tabel maka $\mathrm{H}_{0}$ ditolak dan Ha diterima. Dilihat dari tabel 12, nilai sig pada uji- $\mathrm{t}$ sebesar 0,02 $(\mathrm{p}<0,05)$, maka dapat disimpulkan bahwa hasil dari uji hipotesis ini adalah terima $\mathrm{H}_{\mathrm{a}}$ yang berarti terdapat perbedaan motivasi belajar siswa sebelum menggunakan model pembelajaran kooperatif tipe teams games tournament dengan sesudah menggunakan model pembelajaran kooperatif tipe teams games tournament.

Hasil penelitian ini sejalan dengan penelitian yang dilakukan oleh Yupinda Prima Putri (2016), bahwa model pembelajaran kooperatif tipe teams games tournament berpengaruh positif terhadap motivasi belajar IPA siswa. Dengan menggunakan model pembelajaran kooperatif tipe teams games tournament, maka motivasi belajar siswa dapat meningkat.

Tabel 11.

Nilai Korelasi Product Moment

\begin{tabular}{lcccc}
\hline \multicolumn{3}{c}{ Paired Samples Correlations } & & \\
& & $\mathrm{N}$ & Correlation & Sig. \\
\hline Pair 1 & $\begin{array}{c}\text { PRETEST \& } \\
\text { POSTTEST }\end{array}$ & 26 &, 83 &, 00 \\
\hline
\end{tabular}

Tabel 12.

Hasil Uji Hipotesis Dengan Uji-t

\begin{tabular}{|c|c|c|c|c|c|c|c|c|c|}
\hline \multirow[b]{4}{*}{$\begin{array}{c}\text { Pair } \\
1\end{array}$} & \multirow[b]{4}{*}{ Pretest - } & \multicolumn{5}{|c|}{ Paired Differences } & \multirow[b]{3}{*}{$\mathrm{t}$} & \multirow[b]{3}{*}{$\mathrm{df}$} & \multirow[b]{3}{*}{ Sig. (2-tailed) } \\
\hline & & \multirow{2}{*}{$\begin{array}{c}\text { Mea } \\
\mathrm{n}\end{array}$} & \multirow{2}{*}{$\begin{array}{c}\text { Std. } \\
\text { Deviatio } \\
\mathrm{n} \\
\end{array}$} & \multirow{2}{*}{$\begin{array}{l}\text { Std. } \\
\text { Error } \\
\text { Mean }\end{array}$} & \multicolumn{2}{|c|}{$\begin{array}{l}\text { 95\% Confidence } \\
\text { Interval of the } \\
\text { Difference }\end{array}$} & & & \\
\hline & & & & & Lower & Upper & & & \\
\hline & & 1,03 & 2,18 & ,42 & 15 & 1,92 & 2,42 & 25 & ,02 \\
\hline
\end{tabular}

\section{Simpulan dan Saran}

Berdasarkan hasil pengolahan data dan analisis data yang telah dilakukan, dapat diambil kesimpulan bahwa model pembelajaran kooperatif tipe teams games tournament (TGT) berpengaruh terhadap motivasi belajar IPA kelas IV SDN Kelapa Dua 06 Pagi Jakarta Barat. Lebih jelasnya lagi dapat disimpulkan sebagai berikut. Pembelajaran menggunakan model pembelajaran kooperatif tipe teams games tournament (TGT) berpengaruh terhadap motivasi belajar IPA siswa. Hal ini ditunjukkan bahwa 
dari uji-t pada skala sikap motivasi belajar setelah adanya perlakuan menggunakan model pembelajaran kooperatif tipe TGT menunjukkan bahwa hasil posttest mempunyai mean dan jumlah skor yang lebih tinggi jika dibandingkan dengan hasil pretest. nilai mean untuk data pretest adalah 68,96 sedangkan nilai mean untuk data posttest adalah 70 dan jumlah skor motivasi belajar sebelum diberi perlakuan sebesar 1793 dan jumlah skor sesudah diberikan perlakuan sebesar 1820.

Setelah dilakukan perhitungan statistik diperoleh data bahwa siswa yang memiliki kategori motivasi belajar tinggi sebesar $12 \%$ meningkat menjadi $38 \%$ setelah perlakuan. Siswa yang masuk pada kategori motivasi belajar sedang sebesar $73 \%$ menurun menjadi $54 \%$ setelah perlakuan. Siswa yang masuk pada kategori motivasi belajar rendah $15 \%$ menurun menjadi $8 \%$ setelah perlakuan. Terjadi peningkatan pada siswa yang masuk dalam kategori motivasi belajar tinggi, dan terjadi penurunan terhadap siswa yang memiliki motivasi belajar sedang dan rendah. Hal ini menandakan bahwa penggunaan model pembelajaran kooperatif tipe teams games tournament berpengaruh terhadap motivasi belajar IPA di SDN Kelapa Dua 06 Pagi Jakarta.

Dari uji-t diperoleh p-value 0,02 $(\mathrm{p}<0,05)$ yakni $0,02<0,05$ dan thitung $>$ ttabel yakni 2,42 > 2,05 yang berarti tolak $\mathrm{H} 0$ dan terima Ha bahwa terdapat pengaruh yang positif model pembelajaran kooperatif tipe teams games tournament (TGT) terhadap motivasi belajar IPA siswa kelas IV SDN Kelapa Dua 06 Pagi Jakarta pada tahun ajaran 2016-2017. Dari penelitian yang telah dilakukan ada beberapa saran yang dapat disampaikan antara lain Bagi guru SDN Kelapa Dua 06 Pagi Jakarta Barat, disarankan untuk menggunakan model pembelajaran kooperatif tipe Teams Games Tournament (TGT) dalam pembelajaran untuk meningkatkan motivasi belajar siswa. Model pembelajaran kooperatif tipe temas games tournament masih perlu dikembangkan secara terus-menerus dengan metodel belajar yang relevance, sehingga pengetahuan dan pemahaman yang dioperoleh siswa relatif lebih tahan lama. Bagi siswa, semangat dan keaktifan dalam belajar IPA harus ditingkatkan lagi selanjutnya agar mendapatkan hasil yang lebih memuaskan dari sebelumnya. Perlu adanya penelitian lebih lanjut sebagai pengembangan dari penelitian ini untuk menganalisis variabel yang lain atau pada materi pokok yang berbeda.

\section{Daftar Pustaka}

Desmita. (2016), Psikologi Perkembangan Peserta Didik, PT. Remaja Rosdakarya, Bandung.

Hamdayama, Jumanta. (2016), Metodologi Pengajaran, PT. Bumi Aksara, Jakarta.

Imamah, N. (2012), "Peningkatan Hasil Belajar IPA melalui Pembelajaran Kooperatif Berbasis Konstruktivisme Dipadukan Dengan Video Animasi Materi Sistem Kehidupan Tumbuhan", .Jurnal Pendidikan IPA Indonesia, Volume 1, No. 1, 32-36.

Priansa, Doni Juni. (2014), Kinerja dan Profesionalisme Guru, CV. Alfabeta, Bandung.

Putri, Yupinda Prima. (2016). Pengaruh Model Pembelajaran Kooperatif tipe Teams Games Tournament (TGT) terhadap Motivasi Belajar IPS Siswa Kelas VIII MTs Negeri 1 Tulang Bawang Tahun Ajaran 2015/2016.Skripsi di akses dari http://digilib.unila.ac.id/24801/.

Samatowa, Usman. (2016), Pembelajaran IPA di Sekolah Dasar, PT Indeks, Jakarta.

Slavin, Robert. E. (2016), Cooperative Learning: Teori, Riset dan Praktik. (Terjemahan Narulita Yusron), Nusa Media, Bandung. (Buku asli diterbitkan tahun 2005).

Sugiyono. (2013), Metode Penelitian Kuantitatif Kualitatif dan R\&D, Alfabeta, Bandung.

Suprihatin, Siti. (2015), Upaya Guru dalam Meningkatkan Motivasi Belajar Siswa, Jurnal Pendidikan Ekonomi UM Metro, Volume. 3, No.1, 73-82.

Surna, I. N. \& Pandeirot, O.D. (2014), Psikologi Pendidikan 1, Erlangga.

Syukur, Imam Abdul, dkk. (2014), Pengaruh model pembelajaran teams games tournament termodifikasi berbasis outbound terhadap prestasi belajar fisika ditinjau dari motivasi belajar, Jurnal Pendidikan dan Kebudayaan, Volume. 20, No. 3, 310-327. 
Uno, Hamzah B. (2008), Teori Motivasi dan Pengukurannya, PT Bumi Aksara, Jakarta.

Wisudawati, A.W. \& Sulistyowati, Eka. (2014), Metodologi Pembelajaran IPA, Bumi Aksara, Jakarta.

Zahroh, Aminatul. (2015), Membangun Kualitas Pembelajaran Melalui Dimensi Profesionalisme Guru. Yrama Widya, Bandung. 